\title{
A Homologous Radioimmunoassay for Bullfrog Basic Gonadotropin
}

\author{
SHIGEYASU TANAKA, YOUICHI HANAOKA \\ AND KATSUMI WAKABAYASHI \\ Institute of Endocrinology, Gunma University, \\ Maebashi, 371
}

\begin{abstract}
A double antibody radioimmunoassay (RIA) for the measurement of bullfrog basic gonadotropin (GTH) is described. The antiserum was raised against a highly purified bullfrog basic GTH. Bullfrog basic GTH-IV $(\mathrm{pI}=9.33)$ was used for radioiodination and as a reference standard. The dissociation constant of the binding of the antibody to bullfrog basic GTH-IV was $8.28 \times 10^{-12} \mathrm{M}$. The standard curve was obtained with $0.1-25.6 \mathrm{ng} / \mathrm{ml}$ of bullfrog basic GTH-IV. When bullfrog sera were assayed by this RIA system, the intra-assay coefficient of variation and inter-assay coefficient of variation were $4.45 \%$ and $5.6 \%$, respectively. The accuracy of the assay was shown as the recovery of bullfrog basic GTH-IV added to the pooled bullfrog sera. With a range of $0.1-12.8 \mathrm{ng} / \mathrm{ml}$, the recovery was $104.78 \pm 11.91 \%$ (Mean \pm S.D.). When bullfrog pituitary extract was fractionated by isoelectric focusing (IEF) and assayed for gonadotropin by this RIA system and also by radioreceptor assay systems employing Xenopus or Anolis testicular homogenates, the RIA positive peaks agreed well with those obtained with Xenopus RRA, indicating that the present RIA system measures LH-like gonadotropin. The inhibition curves of pituitary preparations from bullfrog, brown frogs and dark-colored frog were almost parallel to the standard curve, while those of other anuran and urodele species were not. This RIA system was highly sensitive, but allowed only a narrow application, because of species-specificity.
\end{abstract}

Bioassays for amphibian pituitary gonadotropins are very often insufficient in their sensitivity and precision for the measurement of circulating gonadotropins. If a highly sensitive radioimmunoassay (RIA) system is developed for amphibian gonadotropin, it must be very useful for endocrinological studies. Because of species-specificity, in the development of an RIA system for amphibian gonadotropins, it was necessory to obtain a highly purified gonado-

Received October 8, 1982

Reprint requests should be forwarded to SHIGEYASU TANAKA, Institute of Endocrinology, Gunma University. tropins from pituitaries of amphibians. Licht and his co-workers have purified gonadotropins from pituitaries of three species of amphibians (Licht and Papkoff, 1974 ; Licht et al., 1975; Papkoff et al., 1976; Farmer et al., 1977). Daniels et al. (1977; 1980) reported first homologous RIA systems for LH and FSH of Rana catesbeiana, however, their assay performance, and affinity and species-specificity of the antisera were not described, and those assay systems were not available to us. Recently, Takahashi and Hanaoka (1981) obtained a highly purified bullfrog basic gonadotropin (GTH) from pituitaries of $R$. catesbeiana. In the present 
study, we developed a sensitive RIA system for bullfrog basic GTH and examined the crossreactivity of pituitary preparations from various species of amphibian to this RIA system.

\section{Materials and Methods}

\section{Preparation of bullfrog basic gonadotropin (GTH)}

The previous report (Takahashi and Hanaoka, 1981) revealed that bullfrog basic GTH is composed of four components with pIs of $8.80,8.96,9.11$ and 9.33, which are tentatively termed bullfrog basic GTH-I, II, III and IV, respectively. In the Xenopus ovulation bioassay and in the Xenopus radioreceptor assay employing ${ }^{125} \mathrm{I}$-rat $\mathrm{FSH}$ as radioligand and Xenopus testicular homogenates as receptor preparation, basic GTH-I, II and III had similar potencies to that of NIH-LH-B10, while basic GTH-IV was 2-3 times as potent as the other three components (Takahashi and Hanaoka, 1981). In this study, the basic GTH-IV was used as the hormone for radioiodination and as a reference standard.

\section{Production of the antiserum}

A highly purified bullfrog basic GTH-M, which is a mixture of basic GTH-I, II, III and IV preparation, was used to raise antisera in three rabbits. Two hundred micrograms of the hormone, dissolved in $0.5 \mathrm{ml}$ of saline, was emulsified in $0.5 \mathrm{ml}$ of Freund's complete adjuvant with $0.25 \mathrm{mg} M$. Butyricum (DIFCO, Detroit, Mich.) and was given to a rabbit in the several intradermal sites of the back weekly for 2 months. Blood samples were obtained from the ear vein before each injection and tested for antibody titer. After 2 months, the amount of GTH-M was increased to $400 \mu \mathrm{g}$ and was injected six times at 10-day intervals. Eight days after the final injection, the rabbits were bled from the carotid arteries. The sera were separated by centrifugation, added to $0.01 \%$ merthiolate and stored at $-70^{\circ} \mathrm{C}$.

\section{Radioiodination}

Radioiodination of the purified bullfrog basic GTH-IV were carried out according to the chloramine T method of Greenwood et al. (1963) with a minor modification. The labeled hormone was separated with Biogel P-60 (Bio. Rad. Lab., Richmond, Calif.) column (Disposable plastic column; Whale Sci. Inc.).

\section{Radioimmunoassay system}

A double antibody radioimmunoassay system was established. The first incubation was carried out at room temperature overnight after mixing $400 \mu 1$ of $1 \%$ BSA (bovine serum albumin) in phosphate buffered saline (PBS : $0.01 \mathrm{M}$ sodium phosphate and $0.14 \mathrm{M} \mathrm{NaCl}$ containing $0.01 \%$ merthiolate, $\mathrm{pH} 7.5$ ), $200 \mu 1$ of the standard hormone dissolved in $1 \%$ BSA-PBS or assay samples, $100 \mu 1$ of the first antiserum diluted with 1\% NRS (normal rabbit serum) in $0.05 \mathrm{M}$ EDTA-PBS and $100 \mu 1$ of radioiodinated hormone dissolved in 1\% BSA-PBS. After the first incubation, $200 \mu 1$ of goat anti-rabbit gamma-globulin serum (prepared in the Hormone Assay Center) diluted with $0.05 \mathrm{M}$ EDTA-PBS was added, mixed and incubated at $4^{\circ} \mathrm{C}$ overnight. The assay tubes were then centrifuged at $3,000 \mathrm{rpm}$ for $15 \mathrm{~min}$ and the supernatant fluid was removed by suction. The precipitate was counted for radioactivity in an automatic gamma counter (Beckmann 8000). The assay results were expressed as nanograms of bullfrog basic GTH-IV.

\section{Radioreceptor assay $(R R A)$}

For the measurement of GTH activity, the two RRA systems described in the previous report were used (Tanaka et al., 1981); one with Xenopus laevis testicular homogenate as the receptor preparation which is thought to be specific to LH-like GTH (Adachi et al., 1979), and the other with Anolis carolinensis testicular homogenate which seems to be specific to FSH-like GTH, both employing ${ }^{125}$ I-labeled rat $\mathrm{FSH}$ as radioligand.

${ }^{125}$ I-labeled rat FSH was prepared by radioiodination of NIADDK rat I-3 (supplied by the National Pituitary Agency and the Pituitary Hormones and Antisera Center, NIADDK, NIH) with lactoperoxidase according to the method of Miyachi et al. (1972) with minor modification. Nonspecific binding was determined by using 100 I.U. of pregnant mare serum gonadotropin (Sankyo Manufacturing Co.). Results were expressed as micrograms of NIADDK rat FSH I-3.

\section{Isoelectric focusing (IEF) fractionation}

Pituitary extract was prepared by homogenizing one gland from an adult male bullfrog collected early in April with $1 \mathrm{ml}$ of water. The insoluble fragment was removed by centrifugation at 15,000 rpm for $20 \mathrm{~min}$. The IEF fractionation was carried out on $25 \mathrm{ml}$ column with Ampholine pH 3.5-10 (LKB Produkter) at a $1 \%$ concentration, according to the method described in the previous report (Tanaka et al., 1981). After focusing, the solution was eluted at a flow rate of $0.1 \mathrm{ml} / \mathrm{min}$, and $0.45 \mathrm{ml}$ fractions were collected. At the same time, the $\mathrm{pH}$ of each fraction was automatically measured. These fractions were diluted $1: 10$ with Tris- $\mathrm{MgCl}_{2}-\mathrm{BSA}$ [ $40 \mathrm{mM}$ tris-(hydroxymethyl)-aminomethane $\mathrm{HCl}, 5$ $\mathrm{mM} \mathrm{MgCl} 2, \mathrm{pH} 7.5$, containing $1 \% \mathrm{BSA}]$ and stored at $-20^{\circ} \mathrm{C}$ until assay for gonadotropins. These stored sample solutions were further diluted to appropriate volumes with Tris- $\mathrm{MgCl}_{2}-\mathrm{BSA}$ or $1 \% \mathrm{BSA}$ PBS prior to assay. 


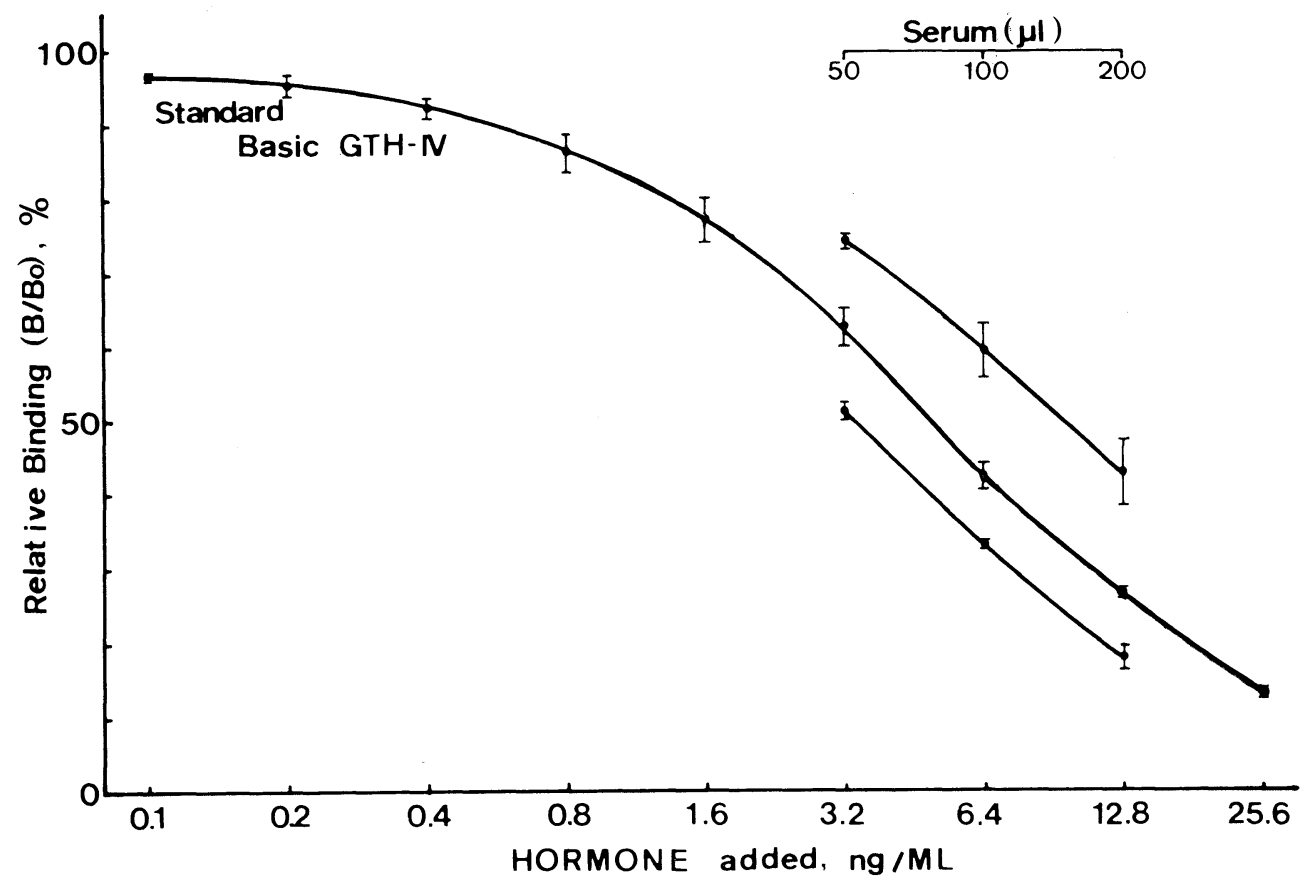

Fig. 1. A standard curve with bullfrog basic GTH-IV and an inhibition curve obtained with sera from bullfrogs. Each point of standard curve represents mean \pm S.D. of triplicated tubes.

\section{Hormone preparations}

To elucidate the specificity of the RIA for bullfrog basic GTH, NIADDK rat FSH I-3, NIADDK ovine LH $\# 21$ and bullfrog acidic GTH $(\mathrm{pI}=6.2$, prepared by Takahashi and Hanaoka, 1981) were used for competitive inhibition of the binding of labeled bullfrog basic GTH-IV.

\section{Pituitary extracts}

The pituitary glands were obtained from amphibians including anuran species; Rana catesbeiana, brown frogs (Rana ornativentris, Rana japonica), dark-colored frog (Rana rugosa), pond frogs (Rana nigromaculata, Rana breviposa, Rana brevipoda porosa), other anuran species (Bufo bufo japonicus, Hyla arborea japonica, Bombina orientalis, Xenopus laevis), and urodele species (Cynops pyrrhogaster pyrrhogaster, Aneides areneus). The glands were homogenized with PBS, then frozen and thawed, and centrifuged at $15,000 \mathrm{rpm}$ for $15 \mathrm{~min}$. The supernatant fluid was stored at $-20^{\circ} \mathrm{C}$ until use. Prior to assay, a part of the supernatant fluid was serially diluted with $1 \%$ BSA-PBS.

\section{Results}

When the antiserum diluted at $1: 128,000$ was incubated with labeled hormone (c. a. $30,000 \mathrm{cpm} /$ tube) in this assay system, approximately $30 \%$ of labeled hormone was bound. Therefore, in the following assay, this dilution of antiserum was used. Fig. 1 shows a standard curve obtained with 0.1$25.6 \mathrm{ng} / \mathrm{ml}$ of bullfrog basic GTH-IV. The sera obtained from adult bullfrogs were assayed by this system in triplicates in three different dilutions. The inhibition curves obtained with these samples were fairly parallel to the standard curve obtained with bullfrog basic GTH-IV. With a range of $0.1-12.8 \mathrm{ng} / \mathrm{ml}$, the recovery of bullfrog basic GTH-IV added to the pooled bullfrog sera was $104.78 \pm 11.91 \%$ (mean \pm standard deviation) (table 1). The mean within-assay 
Table 1. Recovely Test

\begin{tabular}{c|c|c|c|c|c}
\hline & $\begin{array}{c}\text { Number } \\
\text { of tubes }\end{array}$ & $\begin{array}{c}\text { Hormone added } \\
(\mathrm{ng} / \mathrm{ml})\end{array}$ & $\begin{array}{c}\text { Assay value } \\
(\mathrm{ng} / \mathrm{ml})\end{array}$ & $\begin{array}{c}\text { Hormone found } \\
(\mathrm{ng} / \mathrm{ml})\end{array}$ & $\begin{array}{c}\text { Recovery } \\
(\%)\end{array}$ \\
\hline Serum alone & 3 & 0 & 0.495 & - & - \\
Serum + Hormone & 3 & 0.1 & 0.622 & 0.127 & 127 \\
" & 3 & 0.2 & 0.680 & 0.185 & 92.5 \\
" & 3 & 0.4 & 0.864 & 0.369 & 92.3 \\
" & 3 & 0.8 & 1.258 & 0.763 & 95.4 \\
" & 3 & 1.6 & 2.095 & 1.062 & 100.0 \\
" & 3 & 3.2 & 3.802 & 3.307 & 103.3 \\
\hline
\end{tabular}

Accuracy of the RIA is shown as the recovery of bullfrog basic GTH-IV added to the pooled bullfrog sera. Within a range of $0.1-12.8 \mathrm{ng} / \mathrm{ml}$, the recovery percentage was $104.78 \pm 11.91 \%$ (Mean \pm S.D.).

Bullfrog serum (1)

\begin{tabular}{l|r|r|r}
\hline \hline Trial & $\mathrm{N}$ & $\mathrm{ng} / \mathrm{ml}$ & $\mathrm{C} . \mathrm{V}$. \\
\hline 1st. & 3 & 6.631 & 0.28 \\
2nd. & 3 & 5.921 & 6.57 \\
3rd. & 3 & 7.105 & 19.79 \\
4th. & 3 & 6.167 & 4.39 \\
\hline
\end{tabular}

C. V.
Table 2. Precision and Reproducibility Bullfrog serum (2)

\begin{tabular}{l|c|c|c}
\hline \hline Trial & $\mathrm{N}$ & $\mathrm{ng} / \mathrm{ml}$ & C. V. \\
\hline 1st. & 3 & 16.947 & 0.52 \\
2nd. & 3 & 16.868 & 1.66 \\
3rd. & 3 & 17.859 & 0.35 \\
4th. & 3 & 16.637 & 2.04 \\
\hline
\end{tabular}

C. V.

$3.1 \%$

Then mean within-assay coefficient of variation determined from eight triplicates of bullfrog serum samples was $4.45 \%$. The mean between-assay coefficient of variation estimated from the results of 4 consecutive assays of 2 serum samples was $5.6 \%$.

coefficient of variation determined from eight triplicates of bullfrog serum samples was $4.45 \%$. The mean between-assay coefficient of variation estimated from the results of 4 consecutive assays of 2 serum samples was $5.6 \%$ (table 2).

\section{Affinity of the antiserum to bullfrog basic $G T V-I V$}

For the calculation of a specific activity of 125I-labeled bullfrog basic GTH-IV, an aliquot of 125I-labeled bullfrog basic GTHIV was assayed by the RIA system with 131I-labeled bullfrog basic GTH-IV as the labeled antigen. As a result, the labeled bullfrog basic GTH-IV had a specific activity of $140.2 \mu \mathrm{Ci} / \mu \mathrm{g}$. Fig. 2 shows a Scatchard plot drawn from a standard curve obtained with bullfrog basic GTH-IV. The affinity constant $(\mathrm{Ka})$ of the antiserum calculated from this Scatchard plot was $1.28 \times$ $10^{11} \mathrm{M}^{-1}$, and the dissociation constant $(\mathrm{Kd})$ was $8.28 \times 10^{-12} \mathrm{M}$.

Crossreactivity of pituitary preparations with RIA system

Fig. 3 shows the effect of NIADDK rat FSH I-3, NIADDK ovine LH $\$ 21$, bullfrog basic GTH-I, II, III and bullfrog acidic GTH. NIADDK rat FSH I-3 and NIADDK ovine LH $¥ 21$ hardly affected the binding even when large amounts of the hormones were used. The crossreaction of bullfrog acidic GTH was about $10 \%$. Inhibition curves of bullfrog basic GTH-I, II and III were fairly parallel to the standard curve obtained with 
bullfrog basic GTH-IV.

IEF pattern of bullfrog GTHs (Fig. 4)

In the IEF pattern of GTH obtained by Xenopus RRA, two peaks of GTH, one

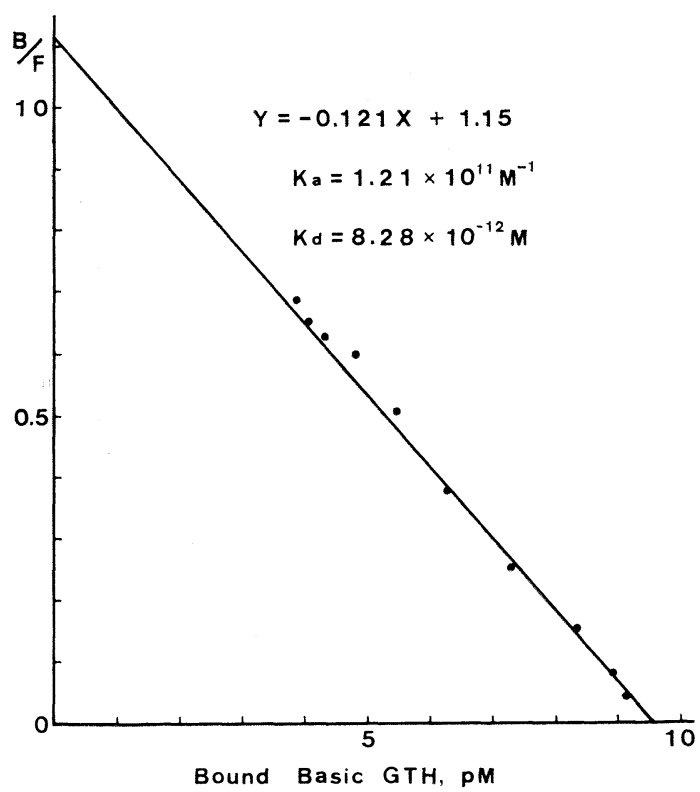

Fig. 2. Scatchard plot of the binding of bullfrog basic GTH-IV to the antiserum. distinct peak and several minor peaks, were recognized at $\mathrm{pH}$ around $10.65-9.10$ and 8.27-6.28, respectively. On the other hand, in the IEF pattern of GTH obtained by Anolis RRA, seven peaks of GTH, three distinct peaks and four less distinct peaks, were found in neutral to acidic $\mathrm{pH}$ region. The major components were at $\mathrm{pH} 7.06$, 6.28 and 5.75. The minors were at $\mathrm{pH}$ $8.27,5.43,5.10$ and 4.85 . When the same IEF fractions were assayed by the present RIA system, we recognized 1 distinct peak at $\mathrm{pH}$ around $10.65-9.10$ and 4 minor peaks at $\mathrm{pH} 8.27,7.60,6.94$ and 6.34 .

Crossreactivity of amphibian pituitary preparations with RIA system

In order to estimate the crossreactivity of gonadotropin of various amphibian species, the crude pituitary extracts were added to this assay system at various concentrations. Pituitary extracts of Rana catesbeiana, $R$. ornativetris, $R$. japonica and $R$. rugosa tested showed inhibition curves parallel with the standard curve obtained with bullfrog basic GTH-IV, while those of R. nigromaculate, $R$. breviposa and $R$. brevipoda porosa did not

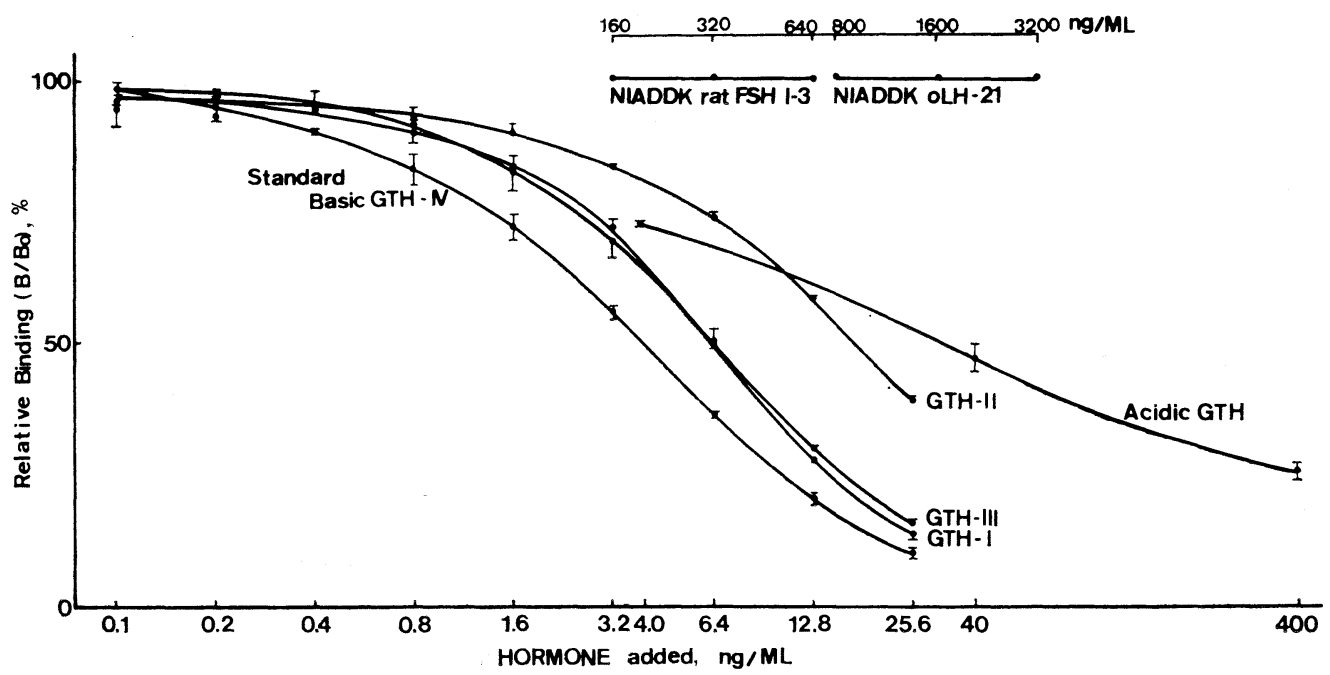

Fig. 3. Competive inhibition curves of various gonadotropin preparations in the RIA for bullfrog basic GTH. Each point on curves represents mean \pm S.D. of triplicated tubes. 


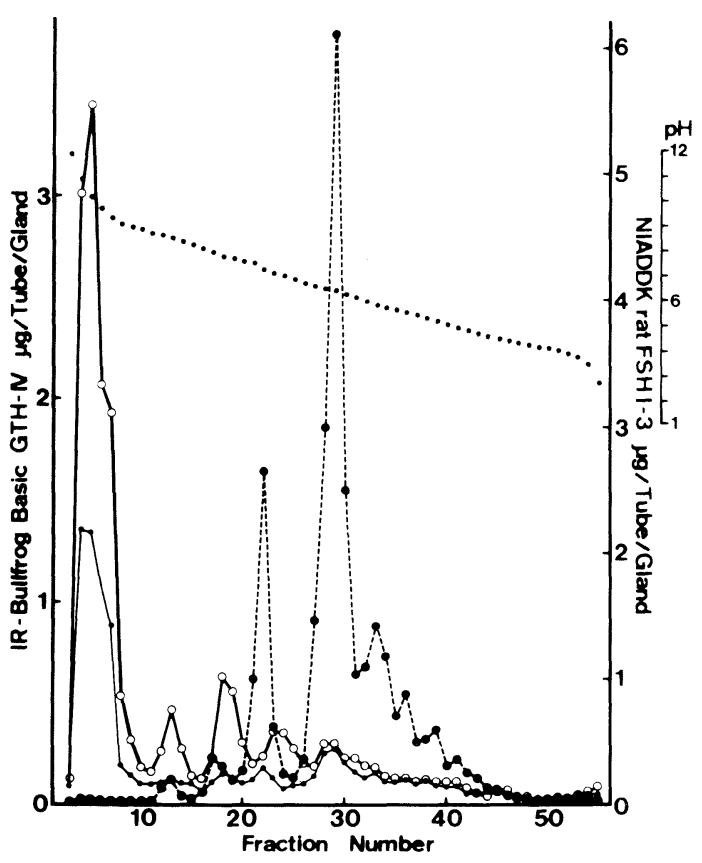

Fig. 4. Isoelectric focusing patterns of pituitary gonadotropins in the adult male bullfrog. Gonadotropins were measured by the RIA $(\mathrm{O}-\mathrm{O})$ or Anolis $(\bullet \cdots \bullet)$ and Xenopus $(\bullet-\bullet)$ RRA. Dots in the figure represent $\mathrm{pH}$ of the fractions.

(Fig 5). Furthermore, no reasonable crossreaction was observed with the extracts from Bufo bufo japonicus, Xenopus laevis, Bombina orientalis, Hyla arborea japonica, Aneides aeneus or Cynops pyrrhogaster pyrrhogaster.

\section{Discussion}

In amphibian, pituitary control of gonadal function was well established (Lofts, 1974). However, the specificity and action of gonadotropin regulating gonadal function is still not clear. One of the reasons may be that the assay methods for GTHs in plasma have been not sufficiently generalized. Although Daniels et al. $(1977 ; 1980)$ established a homologous RIA for frog $\mathrm{LH}$ and FSH, the assay variation and application of the assay system was not reported in detail. Therefore, it was necessary to established a sensitive RIA for amphibian gonadotropin in order to clarify plasma GTH levels. Recently, basic gonadotropin was highly purified from pituitaries of Rana catesbeiana (Takahashi and Hanaoka, 1981). Using the preparation, we developed a sensitive RIA system for

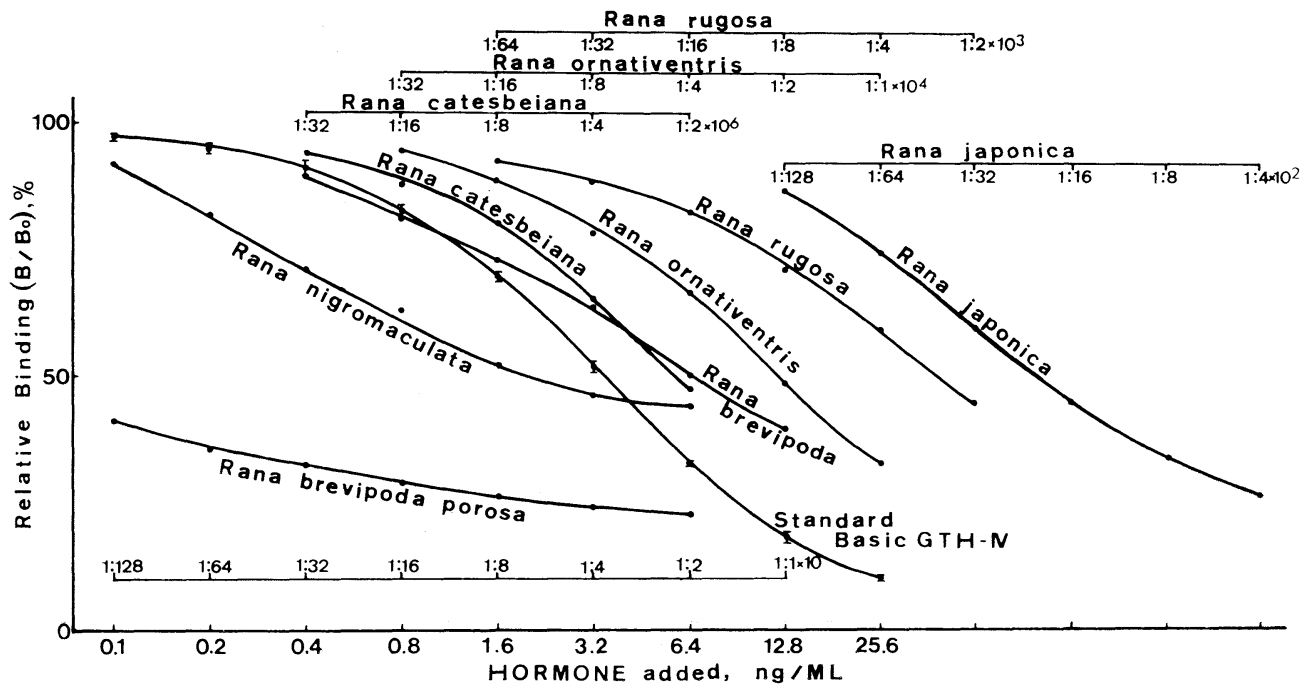

Fig. 5. Competitive inhibition curves of the pituitary extracts from Rana group in the RIA for bullfrog basic GTH. Samples were assayed in triplicate. 
bullfrog basic GTH. Bullfrog basic GTH-M which was used to raise antiserum had the potency of mammalian LH-like hormone (Takahashi and Hanaoka, 1981). The binding of 125I-labeled basic GTH to antiserum was not significantly influenced by highly purified ovine $\mathrm{LH}$ and rat FSH. The inhibition curves of bullfrog basic GTH-I, II and III were fairly paralleled to the standard curve obtained with bullfrog basic GTH-IV. The crossreaction with bullfrog acidic GTH was about $10 \%$. This crossreaction probably is not due to contamination, since both bullfrog GTHs were highly purified. TSH contamination in bullfrog basic GTH-M used as immunogen was not clarified. It was reported that the bullfrog basic GTH-IV used as the hormone for radioiodination has a pI of 9.33 (Takahashi and Hanaoka, 1981). Generally, it was thought that TSH is not found in this high $\mathrm{pH}$ region. Therefore, the contamination of TSH must be neglegible in the bullfrog basic GTH-IV preparation. Even if the anti-bullfrog basic GTH-M contained anti-bullfrog TSH, our RIA system should be fairly specific for bullfrog basic GTH owing to the use of bullfrog basic GTH-IV as the radioiodinated hormone. The IEF profile of bullfrog pituitary extract obtained with RIA also supported this view. When bullfrog GTH activity was assayed by the two RRA systems after IEF fractionation, Xenopus RRA-positive peaks were recognized in the alkaline region, while Anolis RRA-positive peaks were found in the neutral to acidic $\mathrm{pH}$ region. When the same IEF fractions were assayed by this RIA system, the positive peaks agreed well with those obtained with Xenopus RRA. As the Xenopus RRA system is thought to be specific to LH-like GTH in amphibians (Adachi et al., 1979), the present RIA system measures LHlike GTH. In the present study, we used a wide $\mathrm{pH}$ range for IEF to show the IEF profiles of both basic and acidic GTHs. This made the separation of basic GTH IIV insufficient because these basic GTHs appeared in the most alkaline region where the $\mathrm{pH}$ resolution was poor. Precision of the assay is excellent with an inter-assay variation of $4.45 \%$, the intra-assay coefficient of variation being $5.6 \%$. The accuracy of the assay was shown as the recovery of bullfrog basic GTH-IV added to the pooled sera. With a range of $0.1-12.8 \mathrm{ng} / \mathrm{ml}$, the recovery of $104.78 \pm 11.91 \%$ (Mean \pm S.D.) was sufficient. We examined the crossreaction of pituitary extract and serum from thirteen species in seven genera of amphibian. In Rana catesbeiana, the competition curves with pituitary extract and serum were parallel to that of standard bullfrog basic GTHIV, indicating that this RIA system is able to measure basic GTH in plasma and pituitary from Rana catesbeiana. Futhermore, pituitary extracts from brown frogs $(R$. japonica, $R$. ornativentris) ond dark-colored frog $(R$. rugosa) were almost parallel to the standard, but those of other anuran and urodele species were not. Therefore, this RIA system shows a high species-specificity, and does not allow wide application to measure the basic GTH of various species of amphibians. On the other hand, of special interest in the phylogeny of amphibians is the fact that pituitary extracts of the pond frogs i.e. $R$. nigromaculata, $R$. brevipoda and $R$. brevipoda porosa were not parallel to standard curve, because these species belong to the Rana group similar to bullfrog.

\section{Acknowledgements}

We are grateful to Dr. H. Takahashi of the Department of Physical Biochemistry of this Institute for supplying bullfrog gonadotropins and to Dr. A. F. Parlow of the Pituitary Hormones and Antisera Center and National Pituitary Agency, NIADDK for supplying mammalian gonadotropins. We are also grateful to Professor H. Takikawa of this Institute for his encouragement during this work. 


\section{References}

Adachi, T., A. K. Pandey and S. Ishii (1979). Follicle-stimulating-hormone receptors in the testis of the frog, Xenopus laevis. Gen. Comp. Endocrinol. 37, 177-185.

Daniels, E.L., P. Licht, S.W. Farmer and H. Papkoff (1977). Immunochemical studies on the pituitary gonadotropins (FSH and $\mathrm{LH}$ ) from the bullfrog, Rana catesbeiana. Gen. Comp. Endocrinol. 32, 146157.

Daniels, E. and P. Licht (1980). Effect of gonadotropin-releasing hormone on the levels of plasma gonadotropins (FSH and LH) in the bullfrog, Rana catesbeiana. Gen. Comp. Endocrinol. 42, 455-463.

Farmer, S.W., P. Licht, H. Papkoff and E.L. Daniels (1977). Purification of gonadotropins in the leopard frog (Rana pipiens). Gen. Comp. Endocrinol. 32, $158-162$.

Greenwood, F. C., W. M. Hunter and G. S. Glover (1963). The preparation of ${ }^{131}$ I-labeled human growth hormone of high specific radioactivity. Biochem. J. 89, 114-118.

Licht, P. and H. Papkoff (1974). Separation of two distinct gonadotropins from the pituitary gland of the bullfrog Rana catesbeiana. Endocrinology 94, 1587-1594.

Licht, P., S. W. Farmer and H. Papkoff (1975). The nature of the pituitary gonadotropins and their role in ovulation in a urodele amphibian (Ambystoma tigrium). Life Sci. 17, 1049-1054.

Lofts, B. (1974). Reproduction. In : Physiology of the Amphibian II (B. Lofts ed.), Academic Press, New York and London, pp. 107-218.

Takahashi, H. and Y. Hanaoka (1981). Isolation and characterization of multiple components of basic gonadotropin from bullfrog (Rana catesbeiana) pituitary gland. J. Biochem. 90, 1333-1340.

Tanaka, S., H. Takikawa and K. Wakabayashi (1981). Seasonal variation in pituitary gonadotropin in the adult male newt, Cynops pyrrhogaster pyrrhogaster, revealed by isoelectric focusing technique and radioreceptor assay. Endocrinol. Japon. 28, 335345. 